\title{
Quality ladders, growth, and R\&D: an assessment from U.S. industry
}

\author{
Kerk L. Phillips* \\ Brigham Young University, Provo, Utah 84602, U.S.A. \\ and
}

University of Michigan

\begin{abstract}
This paper presents a version of recent Schumpeterian growth models. I present a different specification of preferences, by allowing goods within industries to be substitutes, albeit imperfect ones. I show that assuming $R \& D$ spillovers, which allow easier R\&D for less technologically advanced goods, leads to identical R\&D intensities across goods within an industry. I also show that in the steady-state industries with greater shares in expenditure, greater ease of R\&D and higher markups will experience higher real growth. I then present empirical evidence using Solow residuals from U.S. industry testing these relationships. I find the correlation betwcen technology growth and markups to be weak. There is evidence of a positive impact of company-financed R\&D on technology growth.
\end{abstract}

\section{Introduction}

This paper is concerned with the relationship between economic growth and the profit-maximizing choices of firms. Specifically, it examines the incentives and importance of research and development from the point of view of the firm. The notion that firms contribute directly to economic growth is

*This project benefited tremendously from the able research assistance of Jong-hwa Kim. I have also benefited from discussions and correspondence with Donna Costello, Elias Dinopoulos, Charles Evans, Mary Finn, Roger Kormendi, and Valerie Suslow. The comments of the many other conference participants and the participants in the macro seminar at the University of Michigan were also of great value in refining this paper. I assume responsibility for all errors.

0167-2231/93/\$06.00 ㅇ 1993 - Elsevier Science Publishers B.V. All rights reserved. 
not a new one. It is embodied in Schumpeter's (1942) notion of "creative destruction," for example.

This paper attempts to address several questions. First, how does R\&D effect growth? Second, how and why do industry shares in GNP change over time? Third, how does productivity move over time in U.S. industry? Do industries move together? How is this growth related to R\&D?

I expand on the basic setup of Grossman and Helpman (1991a) and Segerstrom, Anant, and Dinopoulos (1990) by allowing for goods to be substitutes within industries, albeit imperfect ones. The preferences specified are similar to those used by Dinopoulos (1991) with the exception that I do not allow for different qualities of the same good. I derive implications for growth across industries. I show that increased competition in the form of greater substitutability across goods within an industry results in less R\&D activity and lower rates of growth.

Research and development, as the name suggests, is comprised of two similar, but different, processes. For the purposes of this paper let me define research as the discovery of new ideas, concepts, principles, laws of nature, etc. Development, I will define as the incorporation of these ideas into a good or service that can be sold on the market. Development may take two forms: product development, which produces designs for a new good or an improved version of an existing good; and process development, which increases the efficiency of production, leaving product quality unchanged. Both research and development result in nonrival goods. The main difference between the two is that the results of research are primarily nonexcludable while those of development are not. One can think of obvious exceptions to this rule, but it holds in general.

To the extent that the results of research are nonexcludable, firms have little incentive to engage in it. There is a classic free-rider problem that will result in underproduction of research in the market. By the same token, to the extent that development is excludable, there are incentives for firms to develop. Romer (1990b) sets forth a good discussion of these incentives. The basic idea is that excludability, even if only for the short-run, allows firms to earn monopoly profits. From this perspective, product run, allows firms to earn monopoly profits. From this perspective, product and process development are identical. A firm with a new product to sell will be able to undercut the price of its competitors either because its good is of higher quality or because it has lower production costs.

This paper is concerned with the incentives for development and largely ignores the effects of basic research. This does not imply that research is not important. In fact, basic research is necessary for the development process to continue over time. Although research distinct from development is not formally modeled, the reader should think of research as an ongoing activity 
in the background which supplies the basic technology firms embody.

The economic literature on R\&D is by no means new. Schumpeter (1942) proposed a basic link between market structure and R\&D. Arrow (1962) considered the incentives for firms to engage in $\mathrm{R} \& \mathrm{D}$ under unlimited patents. More recent work has considered the effects of patent races, incentives for imitation and preemptive $\mathrm{R} \& \mathrm{D}$, as well as technology licensing and cooperative R\&D - see Tirole (1990) chapter ten for an overview of this literature.

In a series of articles Grossman and Helpman (1991a and 1991b) and Grossman (1990) develop a theory of "quality ladders" where firms engage in both innovative and imitative development. They show that such a model implies steady long-run growth, common growth rates across trading countries, and stochastic product cycles. Segerstrom, Anant, and Dinopoulos (1990) present a model with similar underpinnings but concentrate on a wider range of policy implications. Segerstrom (1991) examines the closed-economy version of the model and considers the effects of allowing for imitation and cartel arrangements. Aghion and Howitt (1992) construct a similar model with innovation in intermediate goods and consider the optimality of laissez faire markets. Dinopoulos (1992) and Cheng and Dinopoulos (1991a, 1991b, $1991 \mathrm{c}, 1991 \mathrm{~d}$ ) in a series of articles add additional complexity to the innovation/imitation dynamics and show that such models can generate cyclical movements in output, investment, interest rates, and other key macroeconomic variables.

In each of these cases development yields goods of higher quality. Each new version of a good yields higher utility per unit of consumption. These increments are assumed to be discrete and nonstochastic; hence the term "quality ladders." It is mathematically equivalent to think of each increment yielding greater productivity. Competitive forces drive price to constant markup over marginal cost, and consumers get greater utility by consuming more units of the good. I will use the latter interpretation in this paper. This is for convenience when confronting the data. It is not clear that measurements of real output adjust adequately for increases in quality. In reality, it is the case that both product and process development occur and since quality increases are probably under-measured, the effects of $R \& D$ will be nnderstated in the data. ${ }^{1}$

The quality ladders models from the literature above and from this paper have implications for the effect of $R \& D$ on economic growth. In addition, there are implications for the effect of competition in both $R \& D$ and production on rate of growth. There is a considerable body of empirical work examining these relationships. Cohen and Levin (1989) give an extensive overview of these studies. Important empirical work examining the relation-

\footnotetext{
${ }^{1}$ In this light, recent work by Feenstra (1991) on the calculation of price indices with new goods looks very interesting.
} 
ship between monopoly power and R\&D has been done by Scherer (1967) and Levin et al. (1985) and others. Cohen and Levin (1989, p. 1078) note that the evidence for a positive correlation between market power and R\&D intensity is "fragile" and state: "A clear implication is that further evaluation... should take place within the context of a more complete model of the determination of technological progress."

Much recent empirical work has focused on tests for spillovers in $R \& D$. Griliches (1991) gives an excellent overview of this literature. He observes that while "... many of the individual studies are flawed and subject to a variety of reservations,... the overall impression remains that $R \& D$ spillovers are both prevalent and important." Most, but certainly, not all of this work focuses on measuring the impact of $R \& D$ for a specific industry. However, Scherer (1982), Griliches and Lichtenberg (1984), and others have considered the effects across a range of industries.

This paper focuses on the movements in productivity across U.S. industries and their relation to R\&D expenditures and market power. I concentrate on the Solow residual as the relevant measure of total factor productivity. Other researchers have examnined the behavior of Solow residuals across industries. Costello (1989) examines their behavior across industries and countries and concludes that they are not correlated across countries within the same industry and only weakly correlated across industries within the same country. Hall $(1990,1988)$ considers the invariance properties of Solow residuals across a wide range of U.S. industries. He concludes that because it is significantly correlated with factors influencing demand, the Solow residual is not a good measure of total factor productivity. Recent work by Finn (1991), however, indicates that the correlations disappear if capital utilization rates are carefully adjusted to account for changes in the price of energy. This seems to say that a form of the Solow residual accounting properly for capital utilization is a good measure of overall productivity.

This paper is organized as follows. Section 2 develops a Schumpeterian model of growth. Section 3 introduces the dataset used to evaluate these predictions and presents descriptive statistics. I examine, for example, the comovement of industry outputs and factor productivity. Section 4 performs simple econometric tests of the hypotheses from the model. Using a limited set of data on R\&D expenditures, I test the effects of market power on R\&D spending. I also test the effects of R\&D spending on industry growth. Section 5 gives concluding remarks, including areas for further research. 


\section{A model of innovation with substitutability within industries}

\section{Preliminaries}

In this section I develop a model of Schumpeterian innovation where goods are imperfect substitutes within industries. Rather than proceeding directly to the formal modeling, let me give a preliminary description first.

The norm in this literature is to assume CDP (Cobb-Douglas with Perfect Substitutes) preferences across goods. This yields constant nominal expenditures for each good and allows one to disassociate the demand for any given good from the prices of other goods. I assume Cobb-Douglas preferences hold across industries, but also assume Dixit-Stiglitz (1977) CES preferences for goods within industries. This formulation is similar to that used by Dinopoulos (1991) with the exception that I am not allowing for differences in quality that yield perfect substitutes. With these preferences prices of goods outside the same industry will not influence demand for a given good, but prices of other goods within the industry will.

Goods are produced with a linear production function using labor as the sole input. Labor supply is inelastic and fixed over time.

Innovation occurs as the result of costly $R \& D$ investment. I assume that although the outcome of any given $R \& D$ project is random, labor inputs are productive since they raise the probability of success. A successful innovation increases the productivity of labor in production (of the targeted good only) by a constant proportion, $\theta>0$.

Imitation is ruled out. This assumption is primarily for ease of analysis. It makes the return on $R \& D$ investment equal to the net expected value of the stream of future monopoly profits. This stream will not last forever as other R\&D firms will attempt to innovate and capture production. Thus, the present value of this stream must include discounting which allows for the probability that it will be lost.

Although there is no physical capital in the model, consumers still have the option of saving via investment in $R \& D$. One way to visualize the investment market is to assume that $R \& D$ firms are organized at the beginning of each period. They target a particular good for improvement and issue stock. With these proceeds firms hire labor and engage in R\&D. At the end of the period some firms will be successful; they begin monopoly production the following period and pay out their profits as dividends. Firms will earn monopoly profits until they are priced out of the market by a new innovator. The remaining unsuccessful firms go bankrupt and pay nothing on their stocks. With a large number of goods and industries consumers may earn a sure return on savings by holding a diversified portfolio of all firms' equities. Alternatively, a financial intermediary could offer a deposit contract with a sure rate of interest and diversify its holdings of stocks. I will assume the 
latter.

Since I will be dealing with a variety of goods prices, each changing stochastically over time, I will report prices in nominal terms. I will use the quantity theory of money to tie down real output. I assume a fixed supply and velocity of money. National product for this economy is the price of all goods times the quantity produced. This equals national income, which is the fixed labor supply times the nominal wage plus monopoly profits. Part of the wages come from the R\&D sector and the rest come from the production sector. National income and product are equal to the fixed nominal money supply. I show below that nominal wages are fixed over time. Since labor productivity is rising over time (albeit in random jumps), the quantity of a particular good produced will tend to rise over time. Aggregate real output is nominal output divided by the price deflator, which will be formally defined below.

\section{Preferences}

I assume consumers maximize expected utility given by eq. (1). This formulation is the discrete time version of preferences commonly assumed in this literature.

$$
U=\sum_{t=1}^{\infty}\left(\frac{1}{1+\rho}\right)^{t-1} \sum_{i=1}^{I} \mu_{i} \ln \left(c_{i t}\right) ; \quad \sum_{i=1}^{I} \mu_{i}=1
$$

The variables and parameters for this and other equations are summarized in Table 1. In eq. (1) $t$ indexes the time period and $i$ indexes the industry. Consumption of industry $i^{\prime} s$ goods is further defined by eq. (2). I think of $\sigma_{i}$ varying by industry, but let me write it for the time-being without the $i$ subscript for notational ease:

$$
c_{i t}=\left[\sum_{j=1}^{J_{i}} \frac{\sigma-1}{c_{j i t}^{\sigma}}\right]^{\frac{\sigma}{\sigma-1}}
$$

Here $j$ indexes the specific good within industry $i$.

The consumer's budget constraint is given by eq. (3).

$$
\begin{gathered}
\sum_{t=1}^{\infty} \delta_{t} \sum_{i=1}^{I} \sum_{j=1}^{J_{i}} p_{j i t} c_{j i t} \leq \sum_{t=1}^{\infty} \delta_{t} w_{t} \equiv W \\
\delta_{t}=\prod_{s=1}^{t} \frac{1}{1+r_{s-1}} ; \quad \delta_{1}=1
\end{gathered}
$$

Units are defined such that the endowment of labor is one. 


\section{Table 1:}

\section{Definition of Symbols}

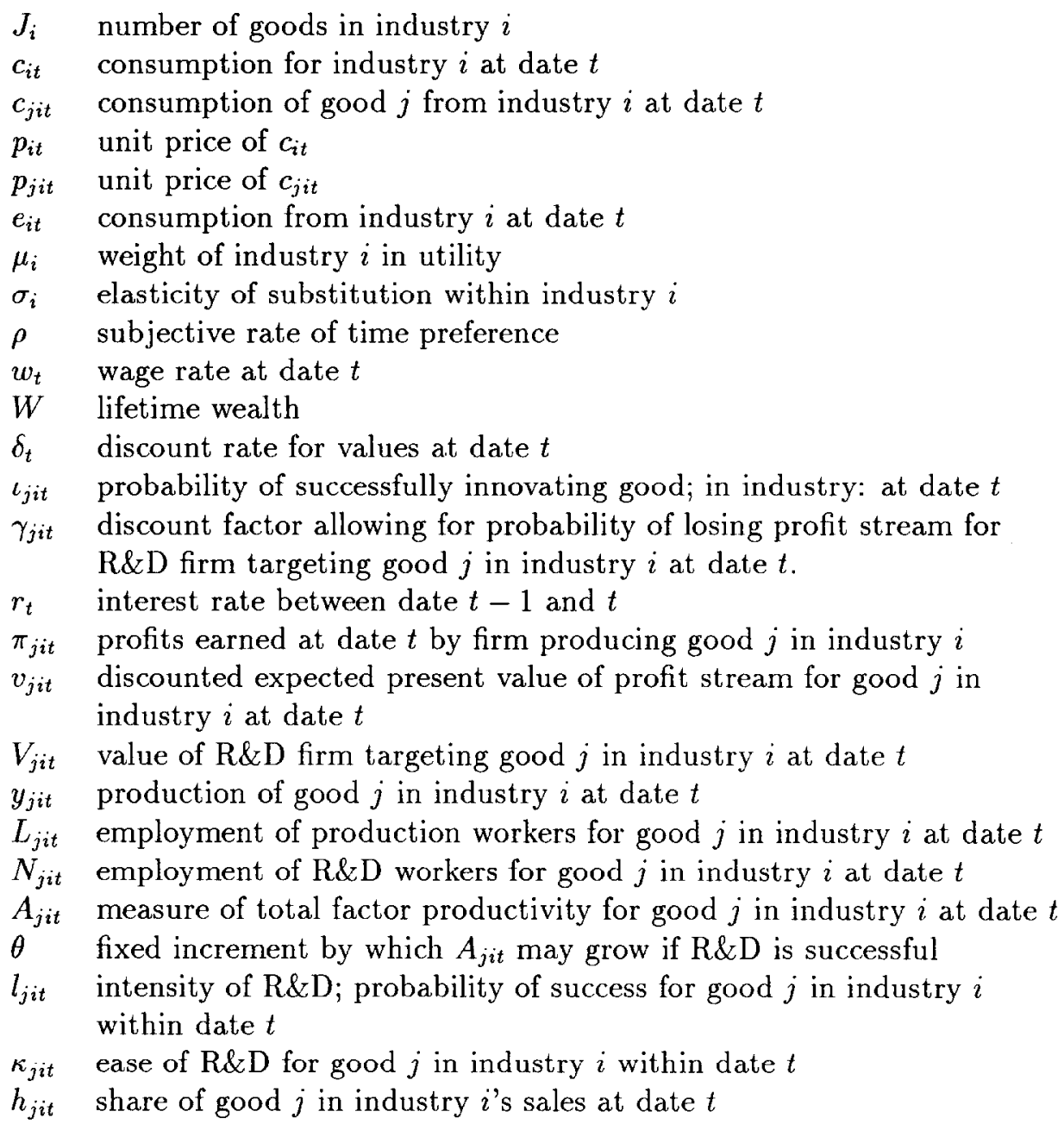


As in Dixit and Stiglitz (1977), I can proceed with a two-stage maximization. For the first stage, if I define the price of industry $i$ output as in eq. (5), I can maximize (1) subject to the budget constraint (3').

$$
\begin{aligned}
& p_{i t}=\left[\sum_{j=1}^{J_{i}} p_{j i t}^{1-\sigma}\right]^{\frac{1}{1-\sigma}} \\
& \sum_{t=1}^{\infty} \delta_{t} \sum_{i=1}^{I} p_{i t} c_{i t} \leq W
\end{aligned}
$$

The first-order conditions from this maximization give the following solution for expenditures on industry $i$ in period $t$.

$$
p_{i t} c_{i t}=\frac{\rho \mu_{i} W}{(1+\rho)^{t} \delta_{t}} \equiv e_{i t}
$$

Eq. (6) shows how expenditures are distributed across time and that expenditure on industry $i$ is just a fraction, $\mu_{i}$, of the period's total expenditures. In the steady state, $r_{t}=\rho \forall t$ and the period's expenditures are a constant fraction, $\rho$, of wealth.

I have made the assumption that labor is inelastically supplied. I could relax this assumption by defining one industry as leisure and $W$ as wealth inclusive of the value of leisure. I would get a fixed expenditure on leisure in the steady state which would translate into a fixed supply of labor.

Since both $W$ and $e_{i t}$ are independent of $p_{j i t}$, as long as a sure rate of return, $r_{t}$, exists each period, the consumer does not need to take the expectation of future prices into account. Once $e_{i t}$ is determined, however, prices will determine its distribution across goods in the industry.

The second stage of the maximization is to maximize eq. (2) subject to (7).

$$
\sum_{j=1}^{J_{i}} p_{j i t} c_{j i t} \leq e_{i t}
$$

The solution is the same as maximizing the natural logarithm of (2), which yields the following first-order condition:

$$
\frac{c_{j i t}}{c_{k i t}}=\left(\frac{p_{j i t}}{p_{k i t}}\right)^{-\sigma} ; \forall j, k
$$

Substituting this into (7), recalling (5), and solving yields the demand for consumption of good $j$ as a function of expenditures and the prices of all goods in the industry:

$$
c_{j i t}=e_{i t} p_{i t}^{\sigma-1} p_{j i t}^{-\sigma}
$$

It can be shown that as long as $J_{i}$ is a large number, the own-price elasticity of demand for $c_{j i t}$ is $\sigma$. 


\section{Production}

All producers are monopolists who have successfully innovated in a previous period, and they will price at a fixed markup over marginal cost.

Let me consider the profit-maximizing decision of an arbitrary monopolist. A firm with a temporary monopoly on the production of a good will mlaximize eq. (10). The firm's production function is given by eq. (11).

$$
\begin{gathered}
\pi_{j i t}=p_{j i t} y_{j i t}-w_{t} L_{j i t} \\
y_{j i t}=A_{j i t} L_{j i t}
\end{gathered}
$$

where $L_{j i t}$ is the employment of labor in production for good $j$ in industry $i$ in period $t$.

Using the first-order condition and the fact that the own-price elasticity of demand for the good is $\sigma$, one can solve for the optimal price charged by the monopolist.

$$
p_{j i t}=\frac{\sigma}{\sigma-1} \frac{w_{t}}{A_{j i t}}
$$

Since marginal cost is simply $w_{t} / A_{j i t}$, eq. (12) shows that price for the monopolist is a fixed markup over marginal cost.

It is important to note here that firms face two types of competitors. First, there is monopolistic competition from substitute goods within the industry. These force the price to its value in (12). There is also direct competition from former producers who could produce identical goods, but at higher cost. Their marginal cost will be $\theta$ times the current producer's. This limits the monopolist's price to $\theta w_{t} / A_{j i t}$. For the purposes of this paper let me assume that $\theta>\sigma /(\sigma-1)$; then the second constraint is never relevant because same-industry goods are sufficiently close substitutes.

Profits for the monopoly firm can be calculated as in eq. (13).

$$
\pi_{j i t}=\frac{1}{\sigma-1} c_{j i t}=\frac{1}{\sigma-1} e_{i t} p_{i t}^{\sigma-1} p_{j i t}^{-\sigma}
$$

\section{$R E D$ structure}

I assume "memoryless" R\&D; that is, a firm's probability of success depends only on current $R \& D$ expenditures and not on past experience. This is standard assumption for this type of model - see Reinganum (1984) for a review. The $R \& D$ structure for this paper is taken from Phillips (1991). $R \& D$ enterprises spring up each period and attempt to improve the efficiency of producing a given good. Phillips (1991) discusses the incentives for firms to enter a given R\&D race and shows that they depend on how profits are divided if more than one firm is successful. Since the resulting aggregate employment is the same for an R\&D monopolist as it is for a large group of 
noncooperative firms, I will assume all $R \& D$ for a given good is done by a single firm.

It is possible that firms may choose to target more than one good. I will follow the convention of referring to each $R \& D$ project as a separate firm, realizing that in this model ownership of the project is unimportant.

R\&D firms are basically in the business of producing a probability. Labor is productive in $\mathrm{R} \& \mathrm{D}$ because it increases the probability of success. I assume that the only way to be successful with probability one is to hire infinite labor and that hiring no labor yields a zero probability of success. Eq. (14) shows the specific functional form of this relationship. This function exhibits decreasing returns to scale, but also implies no special advantage to large firms; see Phillips (1991) for a discussion of these issues. The basic intuition is that a firm consists of atomistic research units working independently. If there is some optimal size for research units, then the firm consists of many of these optimal units.

$$
\iota_{j i t}=1-\exp \left\{-\kappa_{j i t} N_{j i t}\right\}
$$

$N_{j i t}$ is the employment of labor in R\&D for good $j$ in industry $i$ in period $t$, and $\iota_{j i t}$ is the probability of success or intensity of R\&D.

An R\&D firm maximizes the expected net present value of the streamof-monopoly profits less current outlays for employment in R\&D. This value is given by eqs. (15) and (16).

$$
\begin{aligned}
v_{j i t} & =\frac{1}{1+r_{t}} \sum_{s=1}^{\infty} \frac{\delta_{t \mid s} \gamma_{t \mid s} 1}{\delta_{t+1} \gamma_{t}} E_{t}\left\{\pi_{j i t+s}\right\} \\
V_{j i t} & =\iota_{j i t} v_{j i t}-w_{t} N_{j i t} \\
\gamma_{j i t} & =\prod_{s=1}^{t}\left(1-\iota_{j i s}\right)
\end{aligned}
$$

$v_{j i t}$ is the expected net present value of the stream-of-monopoly profits given the firm is successful. $V_{j i t}$ is the value the firm maximizes. $\gamma_{j i t}$ is a factor used to discount profits in the future for the probability that some other firm will successfully innovate and capture production.

Solving the first-order conditions gives the following optimal level of intensity (probability of success) for the firm:

$$
\iota_{j i t}=1-\frac{w_{t}}{\kappa_{j i t} v_{j i t}}
$$

$\kappa_{j i t}$ is the "ease" of R\&D, assuming it is the same for all goods within an industry (i.e., there are no spillover effects of R\&D); eq. (17) implies firms with already high levels of technology will tend to attract higher R\&.D investment than other firms. This is because these firms will have higher 
expected profits due to greater market share. I will formalize this below. For the moment, let me assume that spillovers do exist. I will assume that given the same level of employment in R\&D, a good with a low level of current technology is more likely to yield a successful innovation than a good with currently high technology. Again, I will formalize this below. Let me assume that a formulation exists where the spillover effect exactly balances the market-share effect. This will mean all goods within an industry have an equal probability of innovation. I will assume this for the time being and derive the expected value of an $R \& D$ project. I will then show that this value is consistent with equal $\mathrm{R} \& \mathrm{D}$ intensities across goods within an industry.

Solving eq. (17) requires taking expectations of future profits via eq. (15). Profits are given by eq. (13). If I use eq. (12) and (5) as well I get:

$$
\pi_{j i t}=\frac{e_{i t} A_{j i t}^{\sigma-1}}{\sigma \sum_{k} A_{k i t}^{\sigma-1}}
$$

Let me also calculate the market share of firm $j$ in industry $i$ as follows:

$$
h_{j i t}=\frac{p_{j i t} c_{j i t}}{\sum_{k} p_{k i t} c_{k i t}}=\frac{A_{j i t}^{\sigma-1}}{\sum_{k} A_{k i t}^{\sigma-1}}
$$

I can rewrite eq. (18) as $\left(18^{\prime}\right)$.

$$
\pi_{j i t}=h_{j i t} e_{i t} \sigma^{-1}
$$

Thus, taking expectations of profits requires taking expectations of market share and overall expenditures on the industry. The Appendix shows that as long as there are large numbers of goods in each industry, the expected value of the market share in the future is its value today; i.c., $h_{j i t}$ follows a random walk.

This allows me to simplify eq. (15) to the following (I also restore the industry subscript to $\sigma$ ):

$$
v_{j i t}=\frac{h_{j i t}}{\left(1+r_{t}\right) \sigma_{i}} \sum_{s=1}^{\infty} \frac{\delta_{t+s} \gamma_{t+s-1}}{\delta_{t+1} \gamma_{t}} E_{t}\left\{e_{i t+s}\right\}
$$

Now, let me specify a functional form for the spillover effect via the parameter $\kappa_{j i t}$. I would like this to vary inversely with $h_{j i t}$ in order to offset the market-share effect. Suppose I assume ease of success, $\kappa_{j i t}$, is inversely related to a good's level of technology relative to the industry average as in eq. (20).

$$
\kappa_{j i t}=\kappa_{i} \frac{J_{i}^{-1} \sum_{k} A_{k i t}^{\sigma-1}}{A_{j i t}^{\sigma-1}}=\kappa_{i}\left(J_{i} h_{j i t}\right)^{-1}
$$


Substituting (20) and (15') into (17) I get:

$$
l_{j i t}=1-\frac{J_{i} w_{t}\left(1+r_{t}\right) \sigma_{i}}{\kappa_{i} S_{i t}} ; \quad S_{i t}=\sum_{s=1}^{\infty} \frac{\delta_{t+s} \gamma_{t+s+1}}{\delta_{t+1} \gamma_{t}} E_{t}\left\{e_{i t+s}\right\}
$$

Eq. $\left(17^{\prime}\right)$ shows that the $R \& D$ intensity is the same for each good within an industry, i.e., $\iota_{j i t}=\iota_{i t} \forall j$. This implies that the rate of technological advancement for one good is not tied to other goods in the same industry. Technology for an individual good advances in random discrete jumps and the fact that a good already has a relatively high or low level of technology does not alter its expected rate of progress. Raising $h_{j i t}$ in eq. (20) to a power less than minus one would force goods with high levels of technology to advance less rapidly and lead to common trends in levels of technology for goods within an industry.

Noting eqs. $\left(17^{\prime}\right)$ and $(6)$, it is clear that all else equal, higher shares for an industry in total expenditure will result in greater R\&D intensity and higher rates of technology growth. The same is true for industries with higher $\sigma$ and thus higher markups. Technology in industries where R\&D is relatively difficult $\left(\right.$ low $\left.\kappa_{i}\right)$ will grow more slowly.

\section{Description of the steady state}

If a steady state exists it will be characterized by $r_{t}=r \forall t$. Substituting into eq. (6) and recalling the definition of $W$ shows that expenditures on industry $i, e_{i}$, are constant over time only if $r=\rho$; in which case they are: $(1+\rho) \mu_{i} w$. Profits for industry $i$ will be $\sigma_{i}^{-1}(1+\rho) \mu_{i} w$. Total expenditure on goods, $C$, is: $(1+\rho) w$, and total profits are $\hat{\sigma}^{-1}(1+\rho) w$, where $\hat{\sigma}$ is defined by eq. (21).

$$
\hat{\sigma} \equiv\left[\sum_{i} \frac{\mu_{i}}{\sigma_{i}}\right]^{-1}
$$

Wages from production and R\&D activities will be $w$ each period. Since national income $(w+\pi)$ must equal national expenditure $(C+I)$, investment (and savings) must be equal to:

$$
I=w\left[\frac{1}{\sigma}(1+\rho)-\rho\right]
$$

Individuals have the following sources of income each period: $R \& D$ wages, production wages, interest on savings, principle on savings. They use the first three to purchase goods and hold over the last as savings. The financial intermediary takes deposits of $I$ each period and buys ownership in R\&D firms. Since it owns all firms in the economy, each period it earns dividends equal to all firms' profits which it refunds to consumers in the form of interest payments and principle. 
If I recall eq. $\left(17^{\prime}\right)$ and note that $E_{t}\left\{e_{i t+s}\right\}$ in the steady state is just $e_{i}$, then $I$ can solve for $l_{i}$ as in eq. (23):

$$
l_{i}=\frac{J_{i}^{-1} \kappa_{i} \mu_{i}(1+\rho)-\rho}{J_{i}^{-1} \kappa_{i} \mu_{i}(1+\rho)+\sigma_{i}}
$$

Eq. (23) shows that technology growth is not balanced. Technology in industries with larger shares in total expenditure ( $\mu_{i}$ is large) or where the number of goods is small $\left(J_{i}\right.$ is small) should grow faster as should industries where $\mathrm{R} \& \mathrm{D}$ is less difficult ( $\kappa_{i}$ is large) and where firms can charge higher markups $\left(\sigma_{i}\right.$ is small). Even if $l_{i}$ were equal for all industries, growth would not be balanced, however. As I show below, this implies only that expected rates of growth in technology are the same.

Technology for any given good does not grow smoothly over time. It advances in discrete jumps by a factor of $\theta$ each time. The probability that such a jump will occur in any period is $l_{i}$ in the steady state. The expected growth in technology for good $j$ in industry $i$ is given by:

$$
\frac{E_{t}\left\{A_{j i t+1}\right\}}{A_{j i t}}=\frac{l_{i} \theta A_{j i t}+\left(1-l_{i}\right) A_{j i t}}{A_{j i t}}=l_{i}(\theta-1)+1
$$

Since the probability of a good advancing is independent of relative level technology and does not change over time, the pattern of technology (in logs) for all goods will be nonstationary. The pattern will be akin to a random walk with drift; by assumption, technology cannot move backward. Goods within a given industry will not have common trends. Since the intensity of $R \& D$ varies across industries, goods in industries with higher intensities will have more frequent success and will appear to have a larger drift.

\section{A description of the dataset}

I will test some of the implications of the theory above, using data from U.S. industry. The sources of the data I use are listed at the end of the paper. I gathered annual data on real output, real net capital stocks, employment, and average hours worked per week by industry from 1948 to 1988 . These data were gathered for twenty manufacturing industries as well as for mining, construction, transportation, wholesale and retail trade, and financial services.

In addition, annual data on R\&D for manufacturing industries were gathered for 1963 to 1988 . The data are annual observations of both total industry expenditures and expenditures by companies on $R \& D$. Occasionally the data are aggregated across more than one two-digit SIC code. Table 2 lists the SIC codes for which $R \& D$ data were gathered. $R \& D$ data are not available for industries outside those listed, and there are gaps for some industries 
after 1983. Table 3 lists the average real expenditures for each industry over the sample period as well as the size relative to total value-added.

Table 2:

SIC Definitions

\begin{tabular}{cl}
$\underline{\text { SIC Code }}$ & \multicolumn{1}{c}{ Industry } \\
durables & \\
$24 \& 25$ & Wood, Furniture \& Fixtures \\
30 & Rubber \& Plastics \\
32 & Stone, Clay \& Glass \\
33 & Primary Metals \\
34 & Fabricated Metals \\
35 & Machinery \\
36 & Electrical \& Electronic \\
37 & Transportation Equipment \\
38 & Instruments \\
nondurables & \\
20 & Food \\
$22 \& 23$ & Textiles \& Apparel \\
26 & Paper \\
28 & Chemicals \\
29 & Petroleum
\end{tabular}

The output and factor data were used to construct Solow residuals in the levels. This was done by assuming a Cobb-Douglas production function of the form:

$$
Y_{i t}=A_{i t} K_{i t}^{\alpha_{i}}\left(H_{i t} N_{i t}\right)^{1-\alpha_{i}}
$$

Where $Y$ is real value-added in 1982 dollars, $K$ is the real net capital stock in 1972 dollars, $H$ is the average weekly hours per worker, $N$ is the average number of full-time equivalent workers employed during the year, and $A$ is the Solow residual or level of technology. I was able to construct these series for all industries from 1948 to 1988 . The factor shares $(\alpha)$ were calculated by taking the average of the ratio of nominal total employee compensation to nominal value added over the sample period, as in eq. (26). These values are reported in Table 4 . It was necessary to adjust for the fact that proprietary income is a major source of factor payments for some industries; the values in Table 3 reflect these adjustments.

$$
1-\hat{\alpha}_{i}=\frac{1}{N} \sum_{t=1}^{N} \frac{w_{i t} N_{i t}}{P_{i t} Y_{i t}}
$$


Table 3:

Average Real R\&D Expenditures 1963-1988

\begin{tabular}{ccclcrl} 
Industry & \multicolumn{3}{c}{$\begin{array}{c}\text { By Companies } \\
\text { \$1987 M }\end{array}$} & $\begin{array}{l}\text { Coverage } \\
\text { of v. }\end{array}$ & $\begin{array}{c}\text { T1987 M } \\
\text { \% of v.a. }\end{array}$ & Coverage \\
\hline 24 \& 25 & 135 & $0.43 \%$ & $66-70,75-88$ & 125 & $0.39 \%$ & $63-87$ \\
32 & 516 & $1.93 \%$ & $63-88$ & 460 & $1.88 \%$ & $63-80,86,87$ \\
33 & 684 & $1.40 \%$ & $63-88$ & 750 & $1.59 \%$ & $63-83,87,88$ \\
34 & 566 & $1.06 \%$ & $63-88$ & 625 & $1.16 \%$ & $63-88$ \\
35 & 5719 & $5.92 \%$ & $63-88$ & 5862 & $7.03 \%$ & $63-85$ \\
36 & 6152 & $9.10 \%$ & $63-88$ & 11301 & $18.35 \%$ & $63-88$ \\
37 & 7779 & $8.47 \%$ & $63-88$ & 19644 & $21.43 \%$ & $63-80,86-88$ \\
38 & 1839 & $9.23 \%$ & $63-83$ & 2304 & $11.65 \%$ & $63-83$ \\
20 & 750 & $0.91 \%$ & $64-74,81-88$ & 596 & $0.89 \%$ & $63-80,87$ \\
$22 \& 23$ & 166 & $0.33 \%$ & $63,71-73,81-88$ & 132 & $0.32 \%$ & $63,67,70-80$ \\
26 & 493 & $1.69 \%$ & $63-65,67,72,80-88$ & 435 & $1.71 \%$ & $63-80,82$ \\
28 & 5285 & $8.49 \%$ & $63-88$ & 5721 & $9.49 \%$ & $63-88$ \\
29 & 1457 & $6.80 \%$ & $63-74,76-88$ & 1320 & $7.06 \%$ & $63-80,87,88$ \\
30 & 557 & $2.79 \%$ & $63-73,81-88$ & 689 & $3.65 \%$ & $63-80$
\end{tabular}

The factor shares for production are not measured exactly in the data. Even if the data were exact, they are not precise enough. The data reported for compensation to employees includes payment to workers who are engaged directly or indirectly in the manufacture and sale of goods, as well as payments to workers who engage in R\&D. The former is the correct measure to use when calculating total factor productivity via the Solow residual. The latter should not be counted as part of factor inputs into production. The same is true for capital used in R\&D. Unfortunately there is no way to determine what portion of capital and labor is devoted to $R \& D$ given the data at hand. The data on R\&D expenditures do not distinguish between capital and labor expenditures. I assume (for lack of any better identifying restrictions) that the share of labor in R\&D is identical to the share of labor in production for each industry.

The values of the simple Solow residual calculated from eq. (25) are inflated by a time-invariant percentage which varies from industry to industry depending on how large the R\&D component for that industry is. This does not alter any of the time-series properties of the data, but makes precise comparison of levels of technology across industries impossible. Figures 1 through 4 use markups to correct for this bias.

The theory in Section 1 suggests that industries with high markups should also have high real growth rates. Data on markups are diffiuclt to find, however. I use two sources; the first is to compare the R.\&D data with output data, and the second source is from Hall (1990 and 1988) and Morrison (1992).

In the model's steady state all $R \& D$ is funded by markups over average (which is the same as marginal) cost. Thus, the size of $R \& D$ expenditures 
Table 4:

Industry Factor Shares \& Markups

Markups Over Average Cost Based on R\&D Based on

\begin{tabular}{ccccc} 
Industry & Capital Share & Company & Total & Hall/Morrison \\
\hline $24 \& 25$ & .29 & 1.00 & 1.00 & 1.10 \\
32 & .30 & 1.02 & 1.02 & 1.17 \\
33 & .30 & 1.01 & 1.02 & 1.13 \\
34 & .22 & 1.01 & 1.01 & 1.07 \\
35 & .27 & 1.06 & 1.08 & 1.05 \\
36 & .23 & 1.10 & 1.22 & 1.23 \\
37 & .28 & 1.09 & 1.27 & 1.15 \\
38 & .24 & 1.10 & 1.13 & 1.04 \\
20 & .42 & 1.01 & 1.01 & 1.48 \\
$22 \& 23$ & .19 & 1.00 & 1.00 & 1.06 \\
26 & .35 & 1.02 & 1.02 & 1.30 \\
28 & .45 & 1.09 & 1.11 & 3.12 \\
29 & .54 & 1.07 & 1.08 & 1.15 \\
30 & .28 & 1.03 & 1.04 & 1.06
\end{tabular}




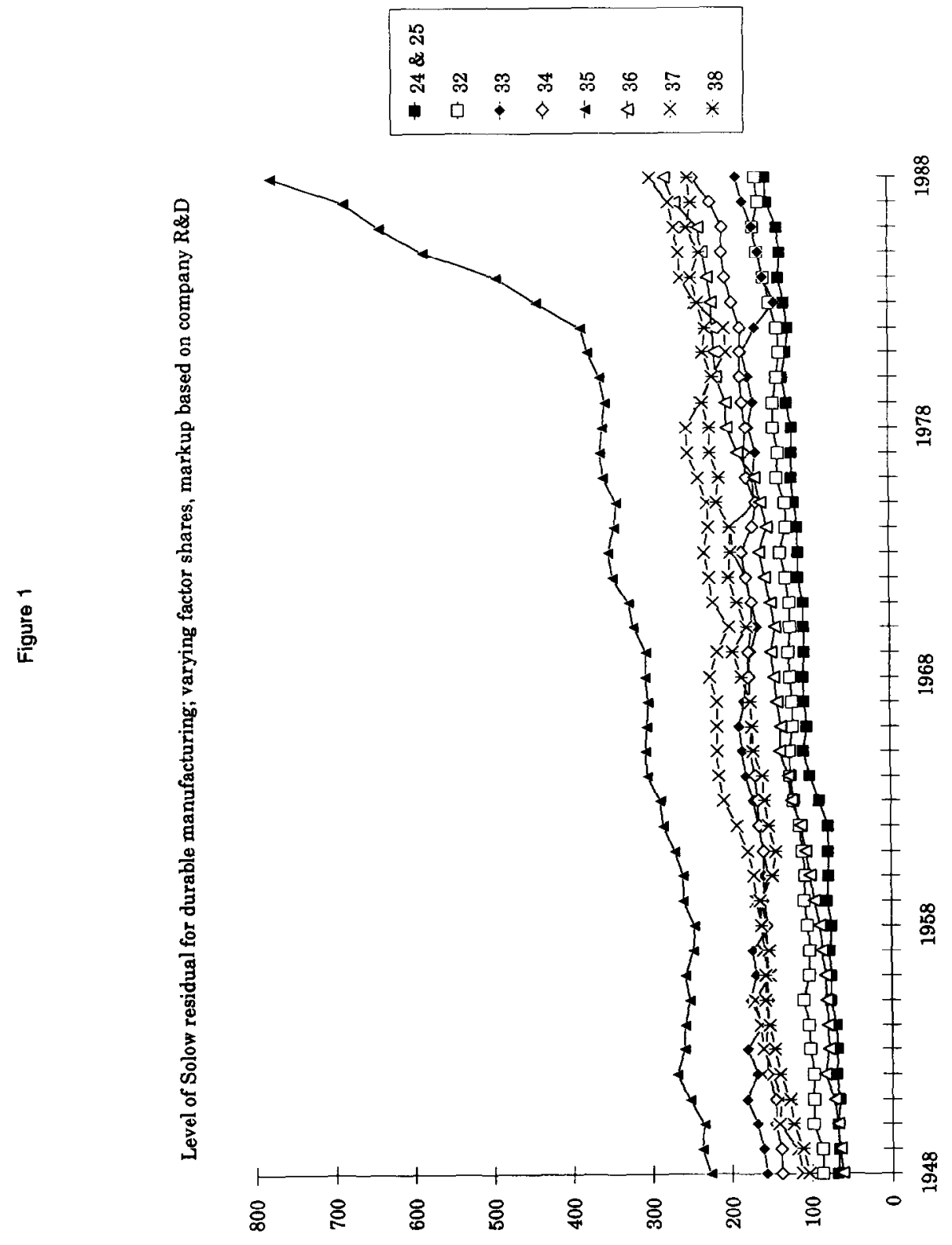




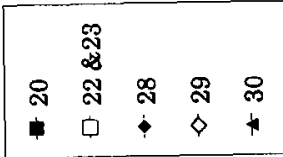

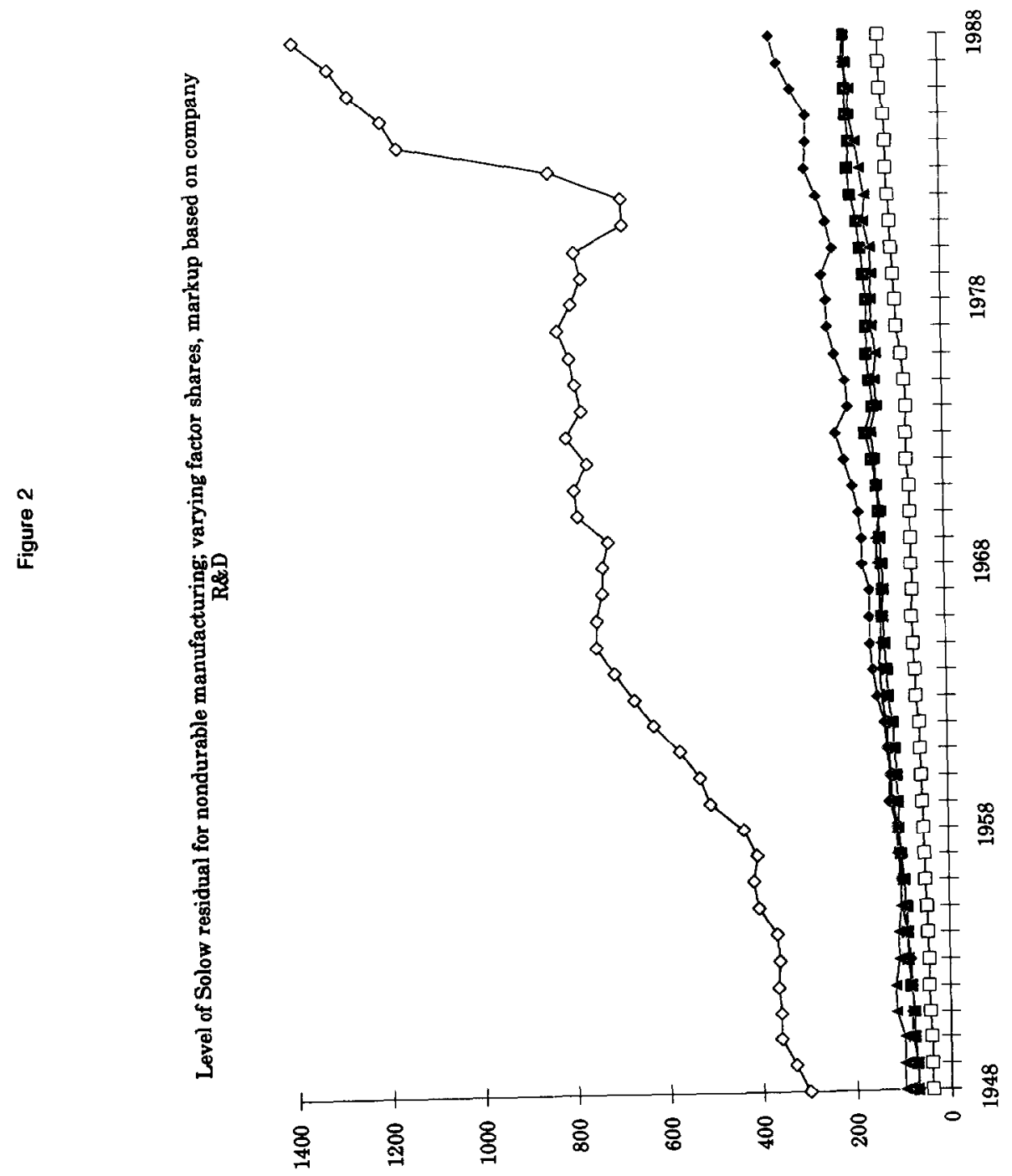




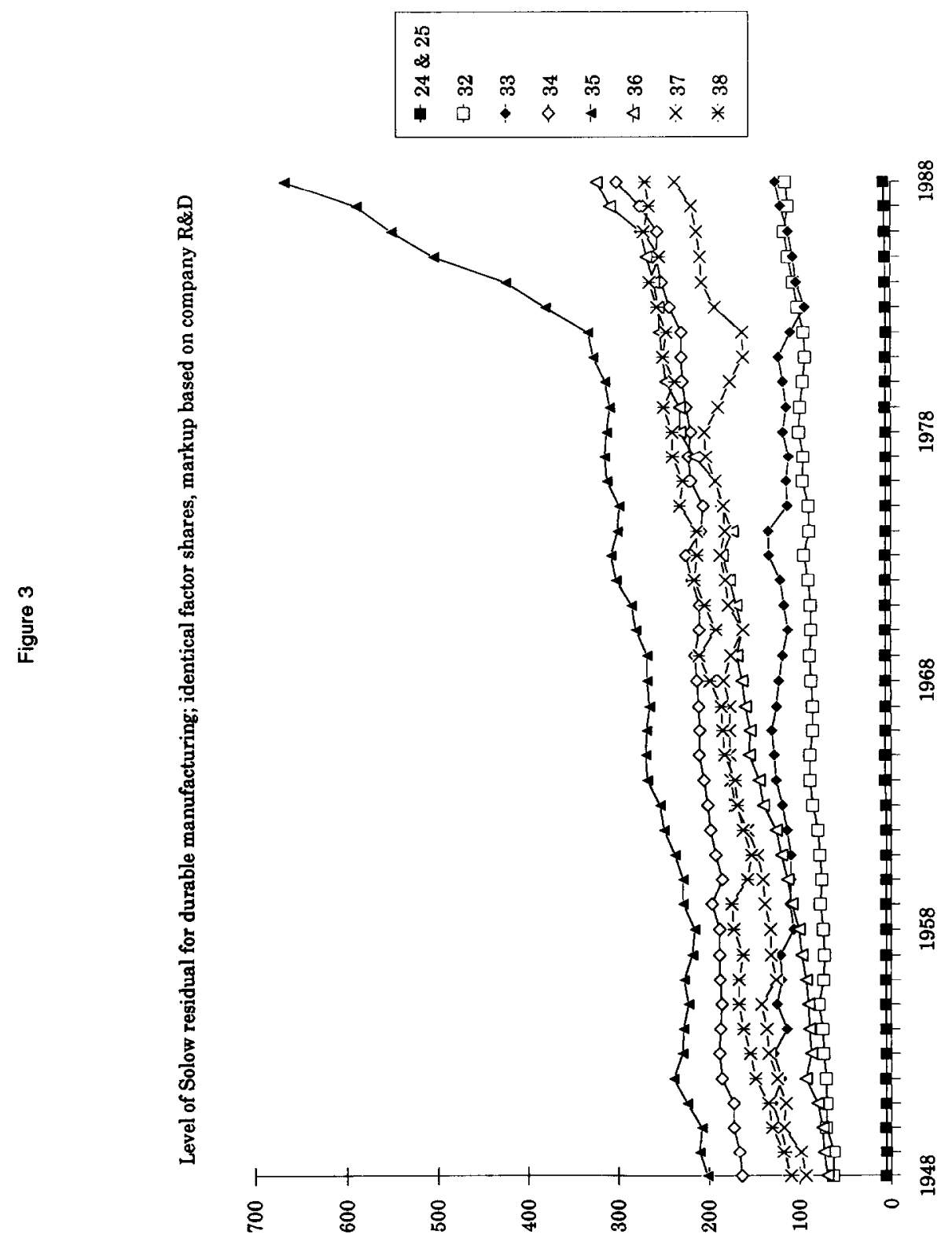




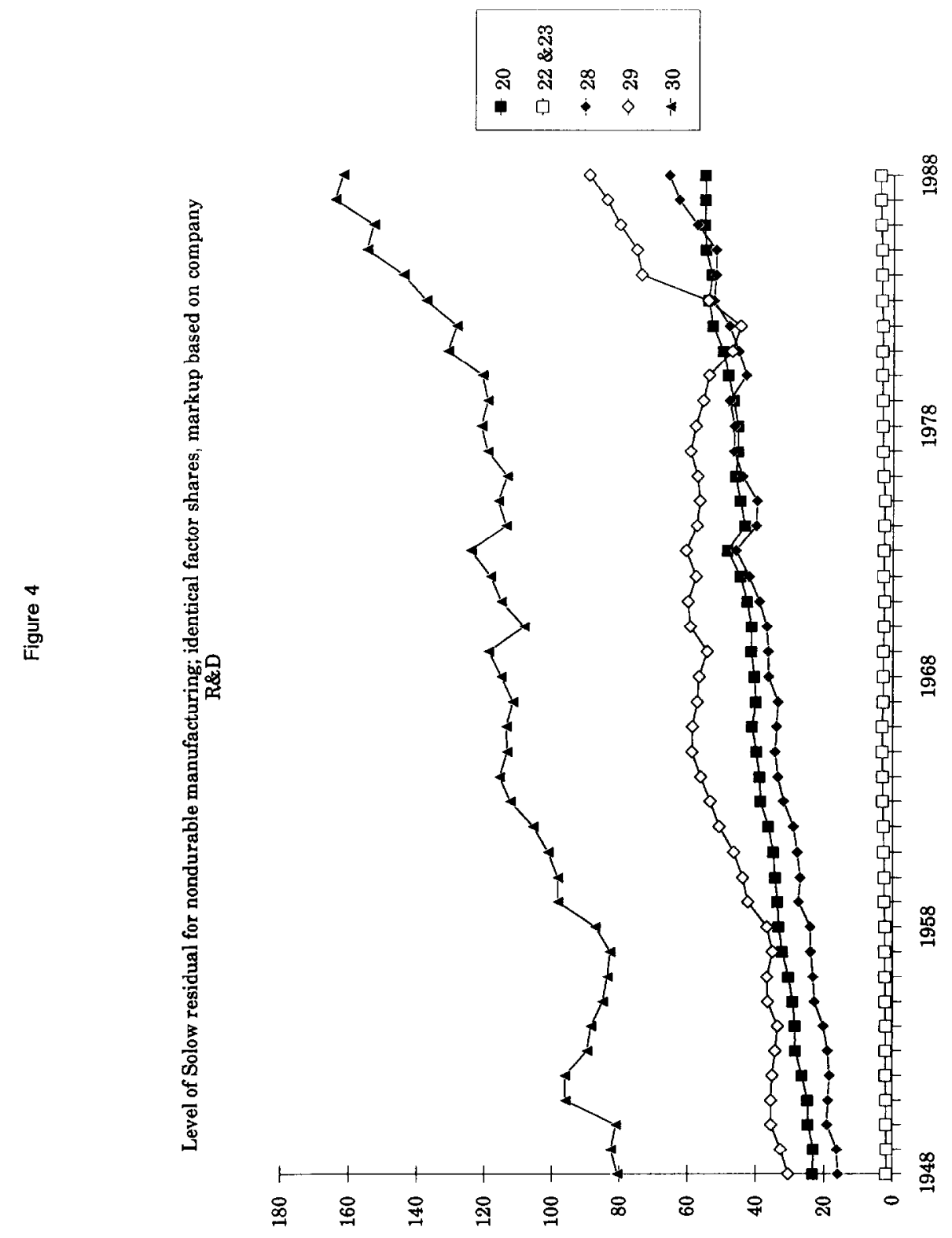


relative to output gives information on the size of markups. These markups are reported in Table 4. These markups are based on a literal interpretation of the model and will be improper if other expenses are also funded out of markups, or if there are significant fixed costs.

Hall (1990 and 1988) provides independent estimates of markups over marginal cost. However, using these in conjunction with my labor compensation data resulted in most cases in negative factor shares for capital. This indicates that many of Hall's estimates are too high for my purposes (working with average cost data). Morrison (1992) reports yearly estimates of markups in manufacturing that are much smaller than Hall's and which imply more reasonable capital shares (in the range of .11 to .25). However, Morrison reports markups for manufacturing as a whole, not by industry. As a first approximation, I assume that Hall's markups are correct in their relative sizes. I then scale them down by a common factor so that they fall into the range of Morrison's estimates. The scaling I use is given in eq. (3.3), where $m_{i}^{H}$ is Hall's estimate of the ratio of price to marginal cost in industry $i, m^{H}$ is the average of these values over all manufacturing industries, and $\bar{m}^{M}$ is the average of Morrison's values from 1960 to 1981 . These values are reported in the last column of Table 4.

$$
\tilde{m}_{i}=1+\left(1-m_{i}^{H}\right) \frac{1-\bar{m}^{M}}{1-\bar{m}^{H}}
$$

I constructed Solow residual using two methods: One way was using the industry-specific $\alpha$ values from eq. (26). The other way was to assume a constant share for all industries of $\alpha=.25$. These time series are plotted in Figures 1 through 4. Durables are shown in Figures 1 and 3, while nondurables are in Figures 2 and 4. Both sets are adjusted for R\&D expenditures, making comparison across industries meaningful.

Whether Solow residuals are appropriate measures of productivity is an unresolved question. Work by Hall (1990 and 1988) and Evans (1992) suggests that they are not invariant to a variety of variables usually associated with aggregate demand movements. Hall shows that industry residuals are not invariant to military spending, the price of oil, or the political party of the president. Evans shows that money, interest rates, and government spending all Granger-cause the residual and that somewhere between a quarter and a half of the residual's variance is attributable to these factors.

One can view the Solow residual being the sum of two components; one related to aggregate demand fluctuations, and the other being true productivity. The econometric tests in the following section look at the linkage between the Solow residual and lagged values of $R \& D$ expenditures. As long as fluctuations in aggregate demand are not correlated with lagged values of $R \& D$ expenditures, the estimated coefficients on $R \& D$ will be consistently estimated. 
In order to get a preliminary assessment of the theory's predictions, I generated a cross-sectional dataset using the 13 industries for which $\mathrm{R} \& \mathrm{D}$ data are available. I calculated the average yearly growth rate of the Solow residual for each industry. I used this in conjunction with the data from Tables 3 and 4.

Recall that the theory above implies that high markups will cause high R\&D expenditures which will, in turn, cause high productivity growth. Table $5 \mathrm{a}$ reports the correlation of $\mathrm{R} \& \mathrm{D}$ expenditures with markups. The Hall/Morrison markups have a weak positive correlation with R\&D expenditures. The other two measures of markups are highly positively correlated with $R \& D$ as they are constructed from the R\&D data. Table $5 b$ reports correlations between $R \& D$ and growth of the Solow residual. This relation is examined in greater detail below. Table $5 c$ reports correlations between markups and growth of the Solow residual. In both cases a generally positive correlation is found.

\section{Empirical tests of the model}

I now perform some formal tests of the predicted relationships from Section 2. Section 2 predicted that high markups, large ratios of nominal expenditure shares to a number of firms, and high ease of $R \& D$ will all lead to higher rates of growth for an industry. The first two effects cause the return on $R \& D$ to increase and will raise the level of expenditure in R\&D activities. The last effect increases the productivity of $R \& D$ and will have an ambiguous effect on R\&D expenditures. (This can be seen by noting that $N=-\ln (\iota) / \kappa$ and eq. (23) which gives the steady state of value of $t$.)

Differences in markups across industries can be measured and are reported in Table 4. It might also be possible to gather data on the number of firms in a particular industry and impute average firm size, or it may even be possible to gather data on average firm size directly. Ease of $R \& D$ is unobservable; it is difficult to think of any data one might gather that would shed light on the value of $\kappa$ across industries.

I test the relationship between $R \& D$ expenditures and productivity growth, realizing that there may well be differences in ease of $R \& D$. I regress the $\log$ difference of both measures of the Solow residual on the various measures of $R \& D$ expenditures.

I first utilize the cross-sectional dataset constructed in Section 3 to calculate simple correlations. Table 6 shows the results of cross-sectional regressions of the average growth of the Solow residual on four measures of $R \& D$ expenditures: company and total expenditures in both real terms and as percentages of industry value-added. While the $R \& D$ variables are significant in most cases when they are the only regressor, adding a constant term reduces 
Table 5: a

Correlation of Markups with R\&D Measures

13 Observations

Markups Over Average Cost

\begin{tabular}{cccc} 
& $\begin{array}{c}\text { Based on R\&.D } \\
\text { Company }\end{array}$ & Total & $\begin{array}{c}\text { Based on } \\
\text { Hall/Morrison }\end{array}$ \\
\hline RC & .832 & .880 & .301 \\
RT & .730 & .938 & .102 \\
PC & .996 & .878 & .340 \\
PT & .916 & .996 & .144
\end{tabular}

Table 5: b

Correlation of R\&D Expenditures with Solow Residual Growth

13 Observations

\begin{tabular}{ccccc} 
& RC & RT & PC & PT \\
\hline GSR1 & .484 & .198 & .444 & .258 \\
GSR2 & .634 & .345 & .649 & .461
\end{tabular}

Table 5: c

Correlation of Markups with

Solow Residual Growth

13 Observations

Markups Over Average Cost

Based on R\&D Based on

\begin{tabular}{lccc} 
& Company & Total & Hall/Morrison \\
\hline GSR1 & .406 & .210 & .416 \\
GSR2 & .610 & .408 & .316
\end{tabular}

$\mathrm{RC} \quad$ average real company expenditures on $\mathrm{R} \& \mathrm{D}$ 1963-83

RT average total real expenditures on R\&D 1963-83

PC average real company expenditures on $R \& D$ as a percent of value-added 1963-83

PT average total real expenditures on $R \& D$ as a percent of value-added 1963-83

GSR1 average growth of Solow residual with industry-specific shares 1963-83

GSR2 average growth of Solow residual with constant. shares 1963-83 
the number of cases.

Table 6:

Cross-Sectional Regression Results

13 Observations

\begin{tabular}{ccc} 
dep. var. & indep. vars. & t-value of R\&D var. \\
\hline GSR1 & RC & $4.024^{3}$ \\
$"$ & RT & $2.433^{2}$ \\
$"$ & PC & $5.288^{3}$ \\
$"$ & PT & $3.579^{3}$ \\
$"$ & RC CONST & 1.762 \\
$"$ & RT CONST & 0.590 \\
$"$ & PC CONST & $1.811^{1}$ \\
$"$ & PT CONST & 0.926 \\
GSR2 & RC & $4.905^{3}$ \\
$"$ & RT & $2.821^{2}$ \\
$"$ & PC & $6.562^{3}$ \\
$"$ & PT & $4.274^{3}$ \\
$"$ & RC CONST & $2.765^{2}$ \\
$"$ & RT CONST & 1.226 \\
$"$ & PC CONST & $2.962^{2}$ \\
$"$ & PT CPNST & $1.803^{1}$
\end{tabular}

GSR1\&2 average yearly growth of Solow residual $1963-88$

RC average real company expenditures on R\&D 1963-88

RT average total real expenditures on R\&D 1963-88

PC average real company expenditures on R\&D as a percent of value-added 1963-88

PT average total real expenditures on $R \& D$ as a percent of valuc-added 1963-88

${ }^{1}$ significant at $90 \%$ confidence

${ }^{2}$ significant at $95 \%$ confidence

${ }^{3}$ significant at $99 \%$ confidence

Since it is hard to draw conclusions from a sample of only 13 observations, I constructed a panel data set which uses yearly observations from 1963-1988 over the set of 13 industries. Due to gaps in the R\&D data, the panel is not complete. I then regress Solow residual growth on the value of $R \& D$ from the previous year, as in eq. (27).

$$
\Delta \ln S R_{t}=\alpha_{0}+\beta_{1} R D_{t-1}+\epsilon_{t}
$$

I also run separate regressions, regressing it on the values of $R \& D$ from the previous five years, to control for the possibility that the gestation period 
of $\mathrm{R} \& \mathrm{D}$ is longer than one year, as in eq. (28). In all these panel regressions, as long as aggregate demand disturbances are uncorrelated with past values of $R \& D$, they can be lumped into the error term, $\epsilon_{t}$.

$$
\Delta \ln S R_{t}=\alpha_{0}+\sum_{s=1}^{5} \beta_{s} R D_{t-s}+\epsilon_{t}
$$

Finally, in both cases I replace the constant term with a full set of industry dummy variables. Table 7 reports the values of $F$-tests on the significance of $R \& D$ variables. The first test reported is for the hypothesis that the coefficients on all the $R \& D$ variables are jointly zero. The second test is for the hypothesis that they sum to zero. For eq. (27) the two tests are obviously identical.

Table 7 shows that total real $R \& D$ expenditures are generally insignificant in explaining the Solow residual. This result was documented in the earlier version of this paper presented at the Conference. A new result is that real company-financed $R \& D$ expenditures are generally significant. When these expenditures are expressed as a percent of industry value-added, they are significant in every case.

These results show support for the theory in Section 1 and seem to indicate that $R \& D$ financed outside companies has less of an impact on productivity growth.

\section{Conclusions and directions for further work}

I have derived a model of product development which implies that, all else equal, industries with larger shares in nominal expenditure, smaller numbers of firms, less perfect substitutes, or easier R\&D processes will spend more on R\&D and will experience faster technology growth. In the long run I find a strong correlation between $\mathrm{R} \& \mathrm{D}$ expenditure and technology growth. I measure the linkage between substitutability and technology using markups and find a weak positive correlation. In the short run, pancl rcgressions using annual data show a significant role for company-financed $R \& D$, while total $R \& D$ has less significance.

It is important at this stage to note that there are limitations with the data that make drawing strong conclusions difficult. The R\&D data are imcomplete and may very well be inconsistently reported across industrics. In addition, the $R \& D$ data include expenditures on basic research. The model attempts to explain only $R \& D$ expenditures which have claimable returns. It is probably the case that noncompany-financed $R \& D$ is primarily basic research and has large spillovers. Thus, it may have only a small effect on the industry in which it is spent but have similarly small effects in all or most other industries. 
Table 7:

Panel Regression Results

\begin{tabular}{|c|c|c|c|c|}
\hline dep. var. & indep. vars. & df & $\begin{array}{l}\text { F-statistics } \\
\text { jointly zero }\end{array}$ & sum to zero \\
\hline \multicolumn{5}{|c|}{ real company R\&D } \\
\hline$\Delta \ln \mathrm{SR} 1$ & CONST RC(1) & 291 & $9.236^{3}$ & - \\
\hline$"$ & DUM RC(1) & 278 & $11.825^{3}$ & - \\
\hline$"$ & CONST RC(1-5) & 202 & $3.177^{3}$ & 0.522 \\
\hline$"$ & DUM RC(1-5) & 189 & 1.299 & 0.118 \\
\hline$\Delta \ln \mathrm{SR2}$ & CONST RC(1) & 291 & $9.872^{3}$ & - \\
\hline$"$ & DUM RC(1) & 278 & $11.970^{3}$ & - \\
\hline$"$ & CONST RC(1-5) & 202 & $3.188^{3}$ & 0.420 \\
\hline$"$ & DUM RC(1-5) & 189 & 1.403 & 0.073 \\
\hline \multicolumn{5}{|c|}{ real total $R \& D$} \\
\hline$\Delta \ln \mathrm{SR} 1$ & CONST RT(1) & 292 & 1.165 & - \\
\hline$"$ & DUM RT(1) & 279 & $6.465^{2}$ & - \\
\hline$"$ & CONST RT(1-5) & 222 & 0.897 & 0.353 \\
\hline$"$ & DUM RT(1-5) & 209 & 1.135 & 0.067 \\
\hline$\Delta \ln \mathrm{SR} 2$ & CONST RT(1) & 292 & $2.904^{1}$ & - \\
\hline$"$ & DUM RT(1) & 279 & $6.225^{2}$ & - \\
\hline$"$ & CONST RT(1-5) & 222 & 1.006 & 0.816 \\
\hline$"$ & DUM RT(1-5) & 209 & 1.007 & 0.017 \\
\hline \multicolumn{5}{|c|}{ percent company $R \& D$} \\
\hline$\Delta \ln \mathrm{SR} 1$ & CONST PC(1) & 291 & $10.185^{3}$ & - \\
\hline$"$ & DUM PC(1) & 278 & $13.246^{3}$ & - \\
\hline$"$ & CONST PC(1-5) & 202 & $4.189^{3}$ & $4.141^{2}$ \\
\hline$"$ & DUM PC(1-5) & 189 & $2.021^{1}$ & 2.119 \\
\hline$\Delta \ln \mathrm{SR} 2$ & CONST PC(1) & 291 & $9.796^{3}$ & - \\
\hline$"$ & DUM PC(1) & 278 & $12.665^{3}$ & - \\
\hline$"$ & CONST PC(1-5) & 202 & $3.935^{3}$ & $3.202^{1}$ \\
\hline$"$ & DUM PC(1-5) & 189 & $2.858^{1}$ & $2.072^{1}$ \\
\hline
\end{tabular}

$\mathrm{RC}(\mathrm{n}-\mathrm{m})$ lags $\mathrm{n}$ to $\mathrm{m}$ of real company expenditures on $\mathrm{R} \& \mathrm{D}$

$\mathrm{RT}(\mathrm{n}-\mathrm{m}) \quad$ lags $\mathrm{n}$ to $\mathrm{m}$ of total real expenditures on $\mathrm{R} \& \mathrm{D}$

$\mathrm{PC}(\mathrm{n}-\mathrm{m}) \quad$ lags $\mathrm{n}$ to $\mathrm{m}$ of real company expenditures on $\mathrm{R} \& \mathrm{D}$ as a percent of value-added DUM full set of industry dummy variables

${ }^{1}$ significant at $90 \%$ confidence

${ }^{2}$ significant at $95 \%$ confidence

3 significant at $99 \%$ confidence 
In addition, it must be noted that the Solow residuals reported do not properly account for changes in quality of output and inputs. Output is quality adjusted only to a very limited extent; the calculation of real valueadded by the Bureau of Economic Research has only limited adjustment for changes in quality. Similarly the capital stock data are based primarily on historic cost and little adjustment is made for improvements in capital goods. The labor-force data are manhours, and are subject to the same criticism that they do not control for variation in the quality of the labor force over time and across industries.

While the results from this paper are interesting, they are only preliminary explorations of the linkages between $\mathrm{R} \& \mathrm{D}$, markups, and productivity growth. They suggest directions for further research.

On the theoretical side, since technology growth is across industries in cointegration [see Costello (1991)], a specification which gives a greater degree of spillover or diffusion should be adopted. This would require altering eq. (20) to include the level of technology in other industries. In this light it would be helpful to test for numbers of common trends. It would be interesting to find out which industries move together and which do not. The methodology adopted by King, Plosser, Stock, and Watson (1991) would be one way to proceed.

Also, it would be useful at some point to add capital to the model and derive implications. It is difficult to test the theory when it omits such an obvious factor. Adding capital, however, will require careful consideration in defining the capital stock. The most logical way to proceed, assuming $N$ capital stocks for each of the $N$ industries, is probably impossible to test due to the lack of data.

In terms of the data there are necessary refinements that should be made.

First, the estimates of markups need to be revised. It appears that Hall's estimates are inconsistent with wage data, and the adjustments I have made are rather ad hoc. If accurate data on payments to capital could be found or constructed, then markups could be calculated as in eq. (29).

$$
m=\frac{Y}{r K+w N}
$$

These would be the markup of price over average cost and not marginal cost. There are problems with this approach that need to be thought out as well. For example, the appropriate interest rate, $r$, needs to be a before-tax return. In addition, capital and labor used in $R \& D$ activities need to be subtracted out as they do not contribute to current production and are paid out of the markup. This may well be impossible to do, but the fact remains that bctter markup estimates are needed. Poor markup estimates will not only affect their observed correlation with technology, but they will also alter 
the estimates of factor shares in production. This in turn alters the values of the Solow residuals by placing more or less emphasis on labor than is correct.

Second, better R\&D data are needed. The dataset is taken from periodic reports from the National Science Foundation and covers a period of only 20 years. In addition, the data for an industry included in one report may be missing in the next. This is particularly true for company-financed R\&D. Even if data covering more industries and longer time periods can be found, there is still a potential problem with the reporting mechanism. Industries dominated by large firms will report more accurate $R \& D$ data as they often have specific $R \& D$ divisions with the firm. Industries dominated by small firms will underreport $R \& D$, as many $R \& D$ activities (particularly process development) may not be distinguishable from production activities in the accounting process. This will bias observed correlations in the direction theory predicts, i.e., that firms with small market share do less R\&D.

All this suggests that a possible way to test the theory might be to bypass $R \& D$ data altogether. $R \& D$ is an endogenous variable in the theory along with technology and output. The exogenous variables are market share, number of firms, degree of substitutability, and ease of R\&D. This suggests a simple regression like that in eq. (30), where all the regressors are the appropriate values expected in the future.

$$
S R_{i t}=\beta_{0}+\beta_{1} S H R_{i t}+\beta_{2} N F_{i t}+\beta_{3} M K U_{i t}+\beta_{4} K_{i t}+\epsilon_{i t}
$$

Except for the last one (ease of R\&D), all of these data should bc available either directly or implicitly in reported data. One could then test the impact of changes in these exogenous variables over time and across industries by assuming that $K$ is uncorrelated with the other regressors and dropping it from the regression.

I have presented a modification of the "quality-ladders" growth theory as well as some assessments of that theory. I have so far let the theory drive the data analysis. The next step is to now let the analysis drive the theory. After proper modifications, additional analysis can be done. Hopefully this iterative procedure will lead to a clear acceptance or rejection of the basic. theory and a better understanding of the growth process. 


\section{Appendix}

This appendix shows that if $R \& D$ intensities across all goods within an industry are identical (i.e., $l_{j i t}=l_{i t} \forall j$ ), then market shares within the industry will follow a random walk.

Recalling eq. (19) I get:

$$
E_{t}\left\{h_{j i t+1}\right\}=E_{t}\left\{\frac{A_{j i t+1}^{\sigma-1}}{\sum_{k} A_{k i t+1}^{\sigma-1}}\right\}
$$

The evolution of technology over time follows:

$$
A_{j i t+1}= \begin{cases}\theta A_{j i t} & \text { with prob. } l_{i} \\ A_{j i t} & \text { with prob. }\left(1-l_{i}\right)\end{cases}
$$

Eq. (32) shows that movements in levels of technology are independent across goods. Using the law of large numbers, this means the numerator and denominator of the r.h.s. of (31) are independent and I can rewrite the equation as:

$$
\frac{E_{t}\left\{A_{j i t+1}^{\sigma-1}\right\}}{E_{t}\left\{\sum_{k} A_{k i t+1}^{\sigma-1}\right\}}=\frac{l_{i}\left(\theta A_{j i t}\right)^{\sigma-1}+\left(1-l_{i}\right) A_{j i t}^{\sigma-1}}{\sum_{k}\left[l_{i}\left(\theta A_{k i t}\right)^{\sigma-1}+\left(1-l_{i}\right) A_{k i t}^{\sigma-1}\right]}=\frac{A_{j i t}^{\sigma-1}}{\sum_{k} A_{k i t}^{\sigma-1}}=h_{j i t}
$$

Which shows that the expected value of market share next period is its value today. 


\section{Data Sources}

Real Output by Industry are from: National Income and Product Accounts var. ed., U.S. Department of Commerce.

Gross and Net Capital Stock Data by Industry are from: Gorman, et al. (1985), "Fixed Private Capital in the United States," Survey of Current Business vol. 65 , no. 7 , pp. 36-59.

Employment and Hours Data by Industry are from: Handbook of Labor Statistics var. ed., U.S. Department of Labor.

R\&D Expenditure Data by Industry are from: Research and Development by Industry var. ed., National Science Foundation.

Updates of Fmployment and Hours Data for some industries were taken from Citibase Databank.

Updates to Real Capital Stock Data for some industries were constructed using data on Real Investment from Citibase Databank.

Proprietary Income Data used to adjust factor shares for some industries were taken from Citibase Databank. 


\section{References}

Aghion, P. and Howitt, P., (1992). A Model of Growth through Creative Destruction. Econometrica, 60: no. 2, 323-352.

Arrow, K., (1962). Economic Welfare and the Allocation of Resources for Inventions. The Rate and Direction of Inventive Activity, R. Nelson, (ed.), Princeton, NJ: Princeton University Press.

Cheng, L.K. and Dinopoulos, E., (1991a). A Schumpeterian Model of Economic Growth and Fluctuations. Unviersity of Florida, manuscript.

Cheng, L.K. and Dinopoulos, E., (1991b). International Schumpeterian Business Cycles and Economic Growth. University of Florida, manuscript.

Cheng, L.K. and Dinopoulos, E., (1991c). Stochastic Schumpeterian Economic Fluctuations. University of Florida, manuscript.

Cheng, L.K. and Dinopoulos, E., (1991d). Schumpeterian Growth and International Business Cycles. University of Florida, manuscript.

Cohen, W.M. and Levin, R.C., (1989). Empirical Studies of Innovation and Market Structure. Handbook of Industrial Organization, Vol. II, R. Schmalensee and R.D. Willig, (eds.), 1060-1107.

Costello, D.M., (1989). A Cross-Country, Cross-Industry Comparison of the Behavior of Solow Residuals. University of Rochester, manuscript.

Costello, D.M., (1991). An International Investigation of the Long-run Properties of Productivity Growth. University of Florida, manuscript.

Dinopoulos, E., (1991). Schumpeterian Product Evolution and Vanishing Growth. University of Florida, manuscript.

Dixit, A.K., (1988). A General Model of R\&D Competition and Policy. Rand Journal of Economics, 19: no. 2, 317-326.

Dixit, A.K. and Stiglitz, J.E., (1977). Monopolistic Competition and Optimum Product Diversity. American Economic Review, 67: no. 3, 297-308.

Deaton, A. and Muellbauer, J., (1980). Economics and Consumer Behavior. Cambridge: Cambridge University Press. 
Domowitz, I., Hubbard, R.G., and Petersen, B.C., (1986). Business Cycles and the Relationship between Concentration and Price-cost Margins. Rand Journal of Economics, 17: no. 1, 1-17.

Evans, C.L., (1992). Productivity Shocks and Real Business Cycles. Journal of Monetary Economics, 29: no. 2, 191-208.

Feenstra, R.C., (1991). New Goods and Index Numbers: U.S. Import Prices. NBER, Working Paper no. 3610.

Finn, M.G., (1991). Energy Price Shocks, Capacity Utilization and Business Cycle Fluctuations. Institute for Empirical Macroeconomics, Discussion Paper no. 50 .

Geroski, P.A., (1990). Innovation, Technological Opportunity, and Market Structure. Oxford Economic Papers, 42: 586-602.

Geroski, P.A., (1991). Innovation and the Sectoral Sources of UK Productivity Growth. Economic Journal, 101: 1438-1451.

Griliches, Z., (1991). The Search for R\&D Spillovers. NBER, Working Paper no. 3768 .

Griliches, Z. and Lichtenberg, F., (1984). Interindustry Technology Flows and Productivity Growth: A Reexamination. Review of Economics and Statistics, 66: 324-329.

Grossman, G.M. and Helpman, E., (1989). Product Development and International Trade. Journal of Political Economy, 97: no. 6, 1261-1283.

Grossman, G.M., (1990). Explaining Japan's Innovation and Trade: A Model of Quality Competition and Dynamic Comparative Advantage. Bank of Japan Monetary and Economic Studies, 8: no. 2, 75-100.

Grossman, G.M., (1991a). Quality Ladders in the Theory of Growth. Review of Economic Studies, 63: 43-61.

Grossman, G.M., (1991b). Quality Ladders and Product Cycles. Quarterly Journal of Economics, 106: no. 2, 557-586.

Grossman, G.M., (1991c). Endogenous Product Cycles. The Economic Jour- 
nal, 101: 1214-1229.

Grossman, G.M., (1991d). Innovation and Growth in the Global Economy. Cambridge, MA: MIT Press.

Hall, R.E., (1988). The Relation between Price and Marginal Cost in U.S. Industry. Journal of Political Economy, 96: no. 5, 921-947.

Hall, R.E., (1990). Invariance Properties of Solow's Productivity Residual. Growth/Productivity/Unemployment, Peter Diamond (ed.). Cambridge, MA: MIT Press, 71-112.

King, R.G., Plosser, C.I., Stock, J.H., and Watson, M.W., (1991). Stochastic Trends and Economic Fluctuations. American Economic Review, 81: no. 4, 819-840.

Krugman, P., (1991). Increasing Returns and Economic Geography. Journal of Political Economy, 99: no. 3, 483-499.

Levin, R.C., Cohen, W.M., and Mowrey, D.C., (1985). R\&D Appropriability, Opportunity, and Market Structure: New Evidence on Some Schumpeterian Hypotheses. American Economic Review, 75: no. 2, 20-24.

Maddison, A., (1987). Growth and Slowdown in Advanced Capitalist Economies: Techniques of Quantitative Assessment. Journal of Economic Literature, 25: 649-698.

Marjit, S., (1991). Incentives for Cooperative and Non-cooperative R and D in Duopoly. Economics Letters, 37: 187-191.

Mokyr, J., (1990). Twenty-Five Centuries of Technological Change: An Historical Perspective. London: Harwood Academic Publishers.

Morrison, C.J., (1992). Markups in U.S. and Japanese Manufacturing: A Short-Run Analysis. Journal of Business and Economic Statistics, 10: no. $1,51-63$.

Phillips, K.L., (1991). Returns to Scale when Production is Uncertain. Michigan Business School, Division of Research, Working Paper no. 665.

Reinganum, J., (1984). Practical Applications of Game Theoretic Models of R\&D. American Economic Review, 74: no. 2, 61-66. 
Rivera-Batiz, L.A., (1989). Growth, Technology, and Trade between Asymmetric countries. University of Chicago, manuscript.

Rivera-Batiz, L.A. and Romer, P.M., (1991a). Economic Integration and Endogenous Growth. Quarterly Journal of Ecnomics, 106: no. 2, 531-556.

Rivera-Batiz, L.A. and Romer, P.M., (1991b). International Trade with Endogenous Technical Change. European Economic Review, vol. forthcoming.

Romer, P.M., (1986a). Increasing Returns and Long-Run Growth. Journal of Political Economy, 94: no. 5, 1002-1037.

Romer, P.M., (1986b). Increasing Returns, Specialization, and External Economies: Growth as Described by Allyn Young. University of Rochester and Rochester Center for Economic Research, working paper no. 64.

Romer, P.M., (1990a). Are Nonconvexities Important for Understanding Growth? American Economic Review, 80: no. 2, 97-103.

Romer, P.M., (1990b). Endogenous Technical Change. Journal of Political Economy, 98: no. 5, S71-S102.

Scherer, F.M., (1967). Market Structure and the Employment of Scientists and Engineers. American Economic Review, 57: 524-531.

Scherer, F.M., (1982). Interindustry Technology Flows and Productivity Growth. Review of Economics and Statistics, 64: 627-634.

Scherer, F.M., (1984). Innovation and Growth: Schumpeterian Perspectives. Cambridge, MA: MIT Press.

Schleifer, A., (1986). Implementation Cycles. Journal of Political Economy, 94: $1163-1190$.

Schumpeter, J.A., (1942). Capitalism, Socialism and Democracy. New York: Harper Brothers.

Segerstrom, P.S., (1991). Innovation, Imitation and Economic Growth. Journal of Political Economy, 99: no. 4, forthcoming.

Segerstrom, P.S., Anant, T.C.A., and Dinopoulos, E., (1990). A Schumpete- 
rian Model of the Product Life Cycle. American Economic Review, 80: no. $5,1077-1091$.

Shapiro, M.D., (1989). Assessing the Federal Reserve's Measures of Capacity Utilization. Brookings Papers on Economic Activity, 181-241.

Solow, R.M., (1957). Technical Change and the Aggregate Production Function. Review of Economic Studies, 39: no. 3, 312-320.

Tirole, J., (1990). The Theory of Industrial Organization. Cambridge, MA: MIT Press. 